\title{
EFEKTIFITAS METODE OUTDOOR-STUDY DALAM UPAYA MENINGKATKAN MOTIVASI BELAJAR PKN SISWA IX-D MTSN 01 KEPAHIANG
}

\author{
ARMIZAH \\ MTsN 01 Kepahiang Bengkulu \\ armizahmpd@yahoo.co.id
}

\begin{abstract}
Learning is complicated process which is influenced by some factors, internal and external factors. The internal factor that is faced by the student in IX D class at MTsN 01 Kepahiang academic year 2018/2019 is low of motivation on learning. Motivation is a main factor in a process of learning because high motivation will increase the result of the study. Beside that, various methods of learning is also needed. One of method that can be used in the class is outdoor study. The research is action research by using two cycles of study, the subject is IX D students of MTsN 01 Kepahiang with total number 31 students. The research is descriptive study, the aim of research is to describe the increasing student's motivation on learning and student's understanding on PKn subject. The result of the research showed that outdoor study method is effective to increase student's motivation.
\end{abstract}

Key word : efektifitas, outdoor-study, motivation learning

\section{PENDAHULUAN}

Belajar adalah suatu proses yang sangat kompleks dan banyak faktor yang mempengaruhinya. Beberapa faktor yang sangat mempengaruhi terciptanya proses belajar mengajar yang diharapkan dan pemahaman siswa yang maksimal terhadap materi pembelajaran baik yang bersifat internal maupun eksternal. Diantara factor internal yang cukup mempengaruhi proses dan hasil belajar adalah motivasi dari siswa itu sendiri.Di MTsN 01 Kepahiang sebagian besar siswa kurang termotivasi dalam belajar PKN, hal ini disebabkan oleh guru yang masih menggunakan metode ceramah sehingga materi yang diajarkan menjadi verbal/hafalan, walaupun sesekali diselingi dengan menggunakan IT (Teknologi Informasi ). Penggunaan Teknologi Informasi tidak selalu bisa digunakan dalam pembelajaran karena keterbatasan jumlah dan sarana pendukung. Kita menyadari bahwa salah satu kelemahan metode ceramah jika diterapkan secara murni adalah tidak melibatkan anak didik secara aktif dalam proses pembelajaran akibatnya 
materi tersebut menjadi kurang menarik. Upaya yang diperkirakan dapat meningkatkan motivasi siswa pada pelajaran PKN adalah dengan menerapkan metode pembelajaran outdoor -study atau metode belajar di luar ruangan kelas dengan pemberian tugas pada siswa. Melalui metode outdoor-study di lingkungan luar sekolah dapat digunakan sebagai sumber belajar dan membuat suasana belajar yang lebih menyenangkan bagi sebagian besar siswa. Peran guru disini adalah sebagai motivator, artinya guru sebagai pemandu agar siswa belajar secara aktif, kreatif dan akrab dengan lingkungaan. Metode Outdoor-study pada pengajaran PKN menjadi sarana memupuk kreatifitas, inisiatif, kemandirian, kerjasama atau gotong royong dan meningkatkan motivasi pada pembelajaran PKN. (Nursid Sumaatmadja, 1996). Dengan demikian diharapkan metode outdoor-study dalam pengajaran PKN dapat meningkatkan motivasi belajar siswa kelas IXD MTsN 01 Kepahiang.

Dari sejumlah permasalahan tersebut di atas sebenarnya ada satu masalah utama yang perlu mendapat perhatian khusus dan segera dilakukan tindakan, yaitu yang berkaitan dengan motivasi siswa. Maka rumusan masalah dalam penelitian ini adalah " Apakah Efektif menerapkan metode outdoor-study untuk meningkatkan motivasi belajar PKN siswa kelas IX-D MTsN 01 Kepahiang “. Berdasarkan uraian di atas, maka tujuan dari penelitian tindakan kelas ini adalah untuk mendeskripsikan peningkatan motivasi belajar PKN siswa kelas IX-D MTsN 01 Kepahiang dengan menerapkan metode outdoor-study.

D. Manfaat Penelitian

Penelitian tindakan kelas ini diharapkan bermanfaat, bagi guru sebagai bahan pertimbangan tentang penggunaan metode outdoor-study dalam pembelajaran PKN dalam rangka menumbuhkan motivasi belajar siswa, sedangkan untuk siswa diharapkan dapat menumbuhkan motivasi dan pemahaman siswa terhadap materi pembelajaran PKN.

\section{KAJIAN TEORI}

\subsection{Pembelajaran PKN}

Hakekat Pendidikan Kewarganegaraan merupakan mata pelajaran yang memfokuskan pada pembentukan diri yang beragam dari segi agama, sosio/cultural, bahasa, usia dan suku bangsa untuk menjadi warga Negara Indonesia yang cerdas, terampil, dan berkarakter yang dilandasi oleh Pancasila dan UUD 1945. Menurut Keputusan. Dirjen Dikti No.267/Dikti / 2000 materi pendidikan kewarganegaraan adalah pendidikan tentang hubungan warga negara dengan Negara,dan Pendidikan Pendahuluan Bela 
Negara (PPBN). Melalui pendidikan kewarganegaraan,warga Negara NKRI diharapkan mampu memahami,menganalisis dan menjawab masalahmasalah yang dihadapi masyarakat,bangsa dan negaranya yang berkesinambungan dan konsisten dengan cita-cita dan tujuan nasionalnya sebagaimana yang digariskan dalam Pembukaan Undang-Undang Dasar 1945. Dalam mengisi kemerdekaan dan menghadapi globalisasi setiap warga Negara NKRI pada umumnya dan para peserta didik pada khususnya harus tetap pada jati dirinya yang berjiwa patriotik dan cinta tanah air di dalam perjuangan non fisik sesuai dengan profesi masing-masing di dalam semua aspek kehidupan.

Khususnya pada jenjang pendidikan dasar dan menengah seyogyanya dikembangkan sebagai pranata atau tatanan social/pedagogis yang kondusif atau memberi suasana bagi tumbuh kembangnya berbagi kualitas pribadi peserta didik. Sekolah sebagai bagian integral dari masyarakat perlu dikembangkan sebagai pusat pembudayaan dan pemberdayaan peserta didik sepanjang hayat, yang mampu member keteladanan, membangun kemauan, dan mengembangkan kreatifitas peserta didik dalam proses pembelajaran demokratis. Berdasarkan teori dan pendapat dari para ahli diatas maka penulis sangat terinspirasi dan termotivasi untuk mengembangkan dan menerapkannya di lingkungan tempat penulis mengabdikan diri sehingga peserta didik mempunyai sikap,wawasan, keterampilan hidup dan kehidupan yang demokratis sesuai dengan Pancasila dan UUD 1945.

\subsection{Metode Outdoor- Study}

Pendekatan pembelajaran di luar kelas (outdoor-study ) adalah sebuah pendekatan pembelajaran yang menggunakan suasana di luar kelas sebagai situasi pembelajaran berbagai permainan sebagai media transformasi konsep - konsep yang disampaikan dalam pembelajaran. (Irawan, A. Dalam Ginting ; 2005 : 37 ). Pendekatan pembelajaran di luar kelas menggunakan beberapa metode seperti penugasan, tanya jawab, dan belajar sambil melakukan atau mempraktekkan dengan situasi belajar sambil bermain. Pendekatan pembelajaran di luar kelas ini memiliki kelebihan yang mendukung pada pembelajaran siswa diantaranya sebagai berikut : (1) Mendorong motivasi belajar siswa, karena menggunakan setting alam terbuka sebagai sarana kelas, untuk memberikan dukungan proses pembelajaran secara menyeluruh yang dapat menambah aspek kegembiraan dan kesenangan, (2).Guru mampu menciptakan suasana pembelajaran yang menyenangkan karena dapat bereksplorasi menciptakan suasana belajar seperti bermain ,(3). Pada pembelajaran di luar kelas siswa menggunakan media pembelajaran yang 
kongkrit dan memahami lingkungan yang ada di sekitarnya. Pada saat pembelajaran digunakan media yang sesuai dengan situasi kenyataannya, yakni berbagai permainan seperti seluncuran, ayunan, jungkat - jungkit dan lain - lain, (4). Mengasah aktivitas fisik dan kreativitas siswa karena menggunakan strategi belajar sambil melakukan atau mempraktekkan sesuai dengan penugasan. Selain memiliki kelebihan, pendekatan di luar kelas sebagai pendekatan pembelajaran karena menggunakan media yang sesuai dengan kenyataannya di arena bermain anak yang dapat memungkinkan anak keterusan bermain di tempat tersebut.

Proses pembelajaran untuk siswa harus benar - benar menyenangkan, sehingga siswa betah untuk belajar. Suasana pembelajaran diciptakan agar tidak ada penekanan psikologis bagi kedua belah pihak, guru dan siswa. Pembelajaran di luar kelas ( outdoor-study ) merupakan salah satu upaya terciptanya pembelajaran, terhindar dari kejenuhan, kebosanan, dan persepsi belajar hanya dalam kelas. Pembelajaran di luar kelas ( outdoor-study ) merupakan pembelajaran yang dilakukan di luar ruang kelas atau di luar gedung sekolah, atau berada di alam bebas, seperti bermain di lingkungan sekitar sekolah, di taman, atau di perkampungan masyarakat sehingga diperoleh pengetahuan dan nilai - nilai yang berkaitan dengan aktivitas hasil belajar terhadap materi yang disampaikan di luar kelas. Dengan memperhatikan beberapa teori dari para pakar diatas maka penulis sangat tertarik dan ingin mencoba mempraktekkkannya dalam pembelajaran PKn, hal ini juga karena kewalahan penulis dalam meningkatkan motivasi belajar PKn siswa MTsN 01 Kepahiang, khususnya IX-D sehingga hasil belajar belum maksimal..

\subsection{Motivasi Belajar}

Motivasi merupakan perubahan energi dalam diri seseorang yang ditandai dengan munculnya feeling dan didahului dengan tanggapan terhadap adanya tujuan (Sardiman.: 2007).Sedangkan belajar adalah suatu proses yang ditandai dengan adanya perubahan pada diri seseorang.Perubahan dalam diri seseorang dapat ditunjukkan dalam berbagai bentuk seperti berubahnya pengetahuannya,pemahamannya,sikap dan tingkah lakunya,keterampilan dan daya reaksinya,daya penerimaannya dan lain-lain aspek yang ada pada individu (Sudjana, 2002 : 280). Untuk mencapai prestasi yang baik disamping kecerdasan, factor rmotivasi juga sangat berpengaruh, sebab tampa adanya motivasi segala kegiatan akan dilakukan kurang efektif dan efesien. Dalam percakapan sehari hari pengertian motivasi sering dikacaukan dengan perhatian seolah-olah kita menonjolkan fungsi pikiran, sedangkan motivasi fungsi rasa, tetapi 
kenyataannya apa yang menarik motivasi menyebabkan kita berperhatian, dan apa yang menyebabkan perhatian kita tertarik motivasipun meyertai kita.

Berdasarkan pendapat dari pakar diatas, penulis sangat menyadari bahwa motivasi belajar sangat mempengaruhi proses pembelajaran, sehingga sangat berpengaruh juga terhadap hasil pembelajaran. Jadi motivasi merupakan factor yang sangat penting dalam proses pembelajaran dan perlu dibahas dalam pembelajara PKN yang sangat membutuhkan motivasi belajar yang tinggi sehingga dapat memaksimalkan hasil pembelajaran PKN.

\section{PEMBAHASAN}

\section{Pembahasan Penelitian}

Dengan memperhatikan hasil observasi proses pembelajaran siklus pertama dan hasil analisis ulangan harian siklus kedua dengan mencoba menerapkan metode pembelajaran outdoor-study, terlihat adanya peningkatan yang cukup signifikan baik dari segi minat belajar maupun hasil belajar, walaupun belum sepenuhnya membuat guru dan siswa merasa puas/ senang yaitu (motivasi / kreatifitas dan keaktifan) siswa pada awalnya hanya $63 \%$ dan pemahaman terhadap materi pelajaran yaitu $71 \%$, tetapi dengan menerapkan metode outdoor-study pada siklus pertama ini (minat / kreatifitas dan keaktifan) siswa bertambah dengan rata-rata $74 \%$ dan Persentase pemahaman terhadap materi pelajaran meningkat menjadi $80 \%$.

Maka pada kompetensi yang sama namun pada indicator yang berbeda dicoba kembali menerapkan metode outdoor-study pada siklus kedua dengan melakukan beberapa perbaikan yang dianggap masih kurang tepat pada siklus pertama.

Dalam siklus ke 2 ini sudah banyak ditemui peningkatan, baik tentang motivasi belajar maupun hasil belajar walaupun masih terdapat kelemahan-kelemahan seperti kerja kelompok belum semua anak terlibat sangat aktif, konsentrasi siswa mudah sekali beralih karena di luar kelas sering kali banyak gangguan misalnya siswa MIN yang asik bermain dan berlarian hilir mudik, karena satu komplek dan satu halaman dengan siswa MIN 03 Kepahiang dan MAN 01 Kepahiang. Oleh karena itu pada siklus kedua ini penulis memilih lokasi yang berbeda tapi masih berada dalam komplek madrasah terpadu, tepatnya yaitu pada halaman hijau yang berada dibelakang ruangan guru dan didepan labor IPA dan labor bahasa. Di lokasi tersebut tampaknya konsentrasi anak lebih baik sehingga 
motivasi/kreatifitas dan keaktifan) siswa meningkat dengan rata-rata 86 $\%$, dan Persentase pemahaman terhadap materi pelajaran yaitu menjadi 100. Hal ini didukung dengan hasil angket yang telah diisi oleh 10 responden, dapat kita simpulkan bahwa 70 \% siswa kelas IX-D sangat setuju belajar diluar kelas, $30 \%$ setuju belajar diluar kelas.

Dengan memperhatikan regulasi yang telah dikemukakan diatas, maka Penerapan Metode Outdoor-Study Dapat Meningkatkan Motivasi Belajar dan Hasil Belajar Siswa IX-D MTsN 01 Kepahiang " dapat diterima “. Hal ini juga sangat didukung oleh hasil dari beberapa responden tentang sikap responden terhadap belajar didalam kelas/ diluar kelas, yang 30 \% menyatakan setuju belajar diluar kelas dan 70\% menyatakan sangat setuju belajar di luar kelas. Ini berarti tidak satupun siswa yang setuju kalau hanya belajar selalu di dalam kelas, khususnya pada mata pelajaran PKn

Berikut ini adalah grafik peningkatan motivasi belajar siswa dan hasil belajar yang diperoleh pada siklus 1 dan siklus 2 dengan menerapkan metode outdoor-study.

Grafik peningkatan ( motivasi belajar, kreatifitas/keaktifan ) dan ketuntasan belajar siklus 1 dan 2

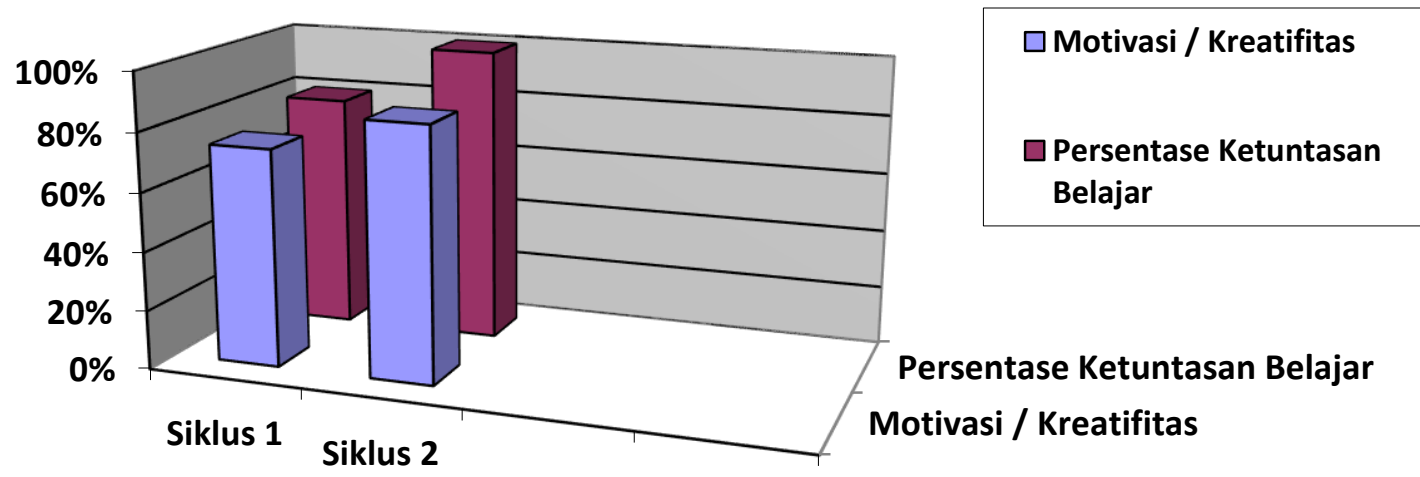




\section{KESIMPULAN DAN SARAN}

\section{Kesimpulan}

Salah satu cara yang dapat dilakukan untuk membangkitkan motivasi belajar PKN adalah dengan memvariasikan berbagai metode pembelajaran. Metode outdoor- study berhasil meningkatkan motivasi belajar PKN siswa kelas IX-D Tahun Pembelajaran 2018/2019 MTsN 01 Kepahiang khususnya pada Materi upaya pembelaan negara. Hal ini terbukti dari hasil penelitian yang dilakukan dalam 2 siklus, antara lain:

a. Metode outdoor-study lebih efisien dan etektif jika diterapkan dengan baik, terutama pada mata pelajaran PKN yang ruang lingkup pengajarannya berupa lingkungan keluarga, masyarakat dan negara yang menjadi ciri khasnya.

b. Metode outdoor-study dapat meningkatkan motivasi belajar PKn, khususnya di kelas IX-D MTsN 01 Kepahiang.

\section{Saran}

1. Setiap guru hendaknya dapat menerapkan berbagai metode pembelajaran sesuai dengan materi dan kompetensi yang diharapkan

2. Guru PKN dapat menerapkan metode outdoor-study melalui karyawisata ketempat-tempat tertentu dengan harapan motivasi belajar siswa terhadap pelajaran PKN meningkat, seperti di laksanakan di kelas IX-D MTsN 01 kepahiang, walaupun hanya belajar dibawah sebuah pohon yang rindang di pekarangan sekolah

3. Para pendidik semestinya terus melakukan inovasi pembelajaran sehingga siswa tidak merasa bosan dan selalu semangat dalam belajar, diantaranya dengan menerapkan metode outdoor -study.

\section{DAFTAR PUSTAKA}

Sardiman.2011.Interaksi dan Motivasi Belajar Mengajar.Jakarta:PT.Raja Grafindo.

Buletin Pelangi Pendidikan (Buletin Peningkatan Mutu Pendidikan SLTP), Volume 6 No. 1 Tahun 2003.

Depdiknas. 2003. Kurikulum 2004 Mata Pelajaran PKN Untuk SMP dan MTS Jakarta : Pusat Kurikulum Depdiknas.

Depdiknas. 2008.BSE PKN Untuk Sekolah Menengah Pertama/MTS kelas IX, Jakarta: CV Teguh Karya 
28 |Efektivitas metode outdoor-...

Effendi. 1995. Filsafat Komunikasi. Bandung; Remaja. Rosdakarya.

http://ekarasi.blogspot.com/2017/2018/hakikat-pembelajaran-pengertian

http://pakguruonline.pendidikan.net ( Diakses Tgl 10 Juni 2018 )

Irawan.2005.Pendidikan Nilai Lokal Sebagai Upaya Membentuk Generasi

Muda. Yang Bermoral. Jurnal Pendidikan Ilmu Sosial.N0

23.Hal.42.Bandung Media Komunikasi Antar FPIPS-UPI,FKIP Universitas/FKIP Se-Indonesia.

Karjawati,1995. Hubungan antara penggunaan metode mengajar,pemanfaatan

lingkungan sebagai sumber belajar dan pengataman mengajar guru dengan

tingkat motivasi beiajar geografi siswa SMA Negeri di Kotamadya

Malang.Skripsi tidak diterbitkan. Malang. Program Sarjana IKIP

Malang.

TIM.2003.Rasio PKN SMP/MTs Kelas IX: Bandung Viva Pakarindo .2006. Standar Isi 2006 Mata Pelajaran PKN SMP/MTS : Jakarta. Pusat Kurikulum Depdiknas 